Arq. Bras. Med. Vet. Zootec., v.66, n.2, p.455-461, 2014

\title{
Oxidative profiles of endurance horses racing different distances
}

[Perfil oxidativo em cavalos de enduro competindo em diferentes distâncias]

\author{
R.F. Siqueira, R.A. Weigel, G. R. Nunes, C.S. Mori, W.R. Fernandes
}

Faculdade de Medicina Veterinária e Zootecnia - Universidade de São Paulo - São Paulo, SP

\begin{abstract}
Increased oxidative stress during prolonged endurance exercises may result in muscle damage, fatigue and decreased performance. An adequate stress response during training is critical to obtain improved results and high animal welfare standards. The aim of this study was to evaluate the red blood cell haemolysate concentrations of superoxide dismutase (SOD), glutathione peroxidase (GPx), reduced glutathione (GSH) and catalase (CAT) and the plasma concentrations of malondialdehyde (MDA) from endurance horses in different distances at high speed in a tropical climate. Fifteen horses were tested; five at $160 \mathrm{~km}(18.54-17.16 \mathrm{~km} / \mathrm{h}$ race speed), five at $120 \mathrm{~km}(21.53-17 \mathrm{~km} / \mathrm{h}$ race speed $)$ and five at $80 \mathrm{~km}(20.06-18.01 \mathrm{~km} / \mathrm{h}$ race speed $)$. Blood samples were collected at rest, immediately after and three hours after the horses left the final vet check and three, seven and fourteen days after the race. No significant increases $(\mathrm{P}>0.05)$ in the levels of SOD, GPx, $\mathrm{GSH}, \mathrm{CAT}$ or MDA were observed for any of the times or distances examined. Based on these observations, we conclude that reactive oxygen species (ROS) formation during exercise evokes specific adaptations, such as increased antioxidant/oxidative damage-repairing enzyme activity, increased resistance to oxidative stress and lower levels of oxidative damage.
\end{abstract}

Keywords: horse, oxidative stress, endurance

\section{RESUMO}

Aumento do estresse oxidativo durante o exercício prolongado pode resultar em fadiga muscular, lesões e diminuição do desempenho. Uma adequada resposta a esse estresse durante o treinamento é fundamental para a obtenção de melhores resultados e bem-estar dos animais. O objetivo deste estudo foi avaliar a concentração de superóxido dismutase (SOD), glutationa peroxidase (GPx), glutationa reduzida (GSH) e catalase (CAT) no hemolisado sanguíneo e malondialdeído (MDA) plasmático em cavalos de enduro correndo em diferentes distâncias, com alta média de velocidade, em clima tropical. Quinze cavalos foram testados, cinco em $160 \mathrm{~km}$ $(18.54-17.16 \mathrm{~km} / \mathrm{h})$, cinco em $120 \mathrm{~km}(21.53-17 \mathrm{~km} / \mathrm{h})$ e cinco em $80 \mathrm{~km}(20.06-18.01 \mathrm{~km} / \mathrm{h})$. Amostras de sangue foram coletadas em repouso, imediatamente e três horas depois que os cavalos passaram pela inspeção veterinária final e três, sete e 14 dias após a corrida. Não houve aumentos significativos $(P>0,05)$ dos níveis de SOD, GPx, GSH, CAT ou MDA em nenhum tempo nem distâncias analisadas. Com base nessas observações, pode-se concluir que as espécies reativas de oxigênio (ROS) formadas durante o exercício provocam adaptações específicas, tais como atividade antioxidante aumentada da enzima, maior resistência ao estresse oxidativo e menores níveis de danos oxidativos.

Palavras-chave: cavalo, estresse oxidativo, enduro

\section{INTRODUCTION}

During aerobic exercise there is an increase in oxygen consumption, and oxidative metabolic pathways are activated. Oxidation produces energy for muscular work as well as the maintenance and integrity of cellular functions. Most of the oxygen consumed forms carbon dioxide and water, but $1-2 \%$ of this oxygen is not completely reduced and instead generates reactive oxygen species (ROS), or free radicals (Williams et al., 2004).

The formation of free radicals occurs normally in the body and has beneficial functions, including energy production and the initiation of apoptosis

Recebido em 18 de maio de 2012

Aceito em 11 de novembro de 2013

E-mail: refarinelli@yahoo.com.br 
and phagocytosis. All cells have antioxidant defence systems, which are divided into enzymatic and non-enzymatic systems that are capable of mitigating the deleterious effects of these substances. The enzymatic group includes the superoxide dismutase (SOD), catalase (CAT) and glutathione peroxidase (GPx) enzymes. In addition, catalase plays an important role in the elimination of hydrogen peroxide and promotes its catalysis to water. GPx converts reduced glutathione (GSH) to oxidised glutathione (GSSG), removing hydrogen peroxide and forming water. Superoxide dismutase catalyses the dismutation of superoxide into oxygen and hydrogen peroxide. The non-enzymatic system includes compounds synthesised by the body, such as bilirubin, ceruloplasmin, melatonin, coenzyme Q, uric acid and other compounds ingested through the diet, such as ascorbic acid, tocopherols, $\beta$-carotene and certain groups of phenolic plant compounds (Schneider and Oliveira, 2004). However, when the production of free radicals exceeds the cellular antioxidant capacity, oxidative stress occurs and can cause muscle disorders and fatigue, as well as a number of diseases reported in humans, such as cancer and Alzheimer's disease (Marlin et al., 2002). ROS can be produced from endogenous sources, such as mitochondria, peroxisomes, and inflammatory cell activation and exogenous sources, including environmental agents, pharmaceuticals, and industrial chemicals. This oxidative stress, in turn, may cause DNA, protein, and/or lipid damage, leading to changes in chromosome instability, genetic mutation, and/or modulation of cell growth that may result in cancer (Klaunig et al., 2010).

Exercise can stimulate the excessive formation of free radicals, as the increase in blood flow and oxygen consumption by muscle fibres during exercise results in electron leakage from the mitochondrial electron transport chain and the production of superoxide anions. During intense exercise muscle fibres can become hypoxic, resulting in ischemia-reperfusion injury. Damaged tissues activate inflammatory cells, such as neutrophils, which produce free radicals through the NADPH oxidase activity. Moreover, the increased production of catecholamines during exercise causes the increased production of reactive oxygen species for their degradation. Hyperthermia can also trigger oxidative stress by increasing lipid peroxidation and glutathione oxidation in erythrocytes. The auto-oxidation of oxyhaemoglobin and methaemoglobin produces superoxide anions, and the formation of these compounds is increased during aerobic exercise (Deaton and Marlin, 2003).

If exercise is viewed as a form of stress, chronic exposure to exercise, i.e., training, may cause changes in response to the increased production of free radicals (Schneider and Oliveira, 2004). Adaptive responses occur because transcription factors sensitive to oxidative imbalance and signalling pathways are induced by exercise. Endurance training causes changes in gene expression in skeletal the muscle mitochondrial DNA, modulating energy metabolism and increasing its biogenesis and cellular antioxidant defences (Radak et al., 2008).

The increase in mechanical, metabolic and physiological work during exercise results in several changes in different organs. During rest, the body recovers and compensates for the stressor effects. Therefore, exercise must cause some level of stress for adaptations to occur. Low workloads lead to low physical fitness levels, but high stress loads are required for welltrained athletes; there is no adaptation without fatigue (Radak et al., 2008).

Equestrian endurance is typically an aerobic discipline, but elite horses are being required to perform at increasingly higher speeds, making this sport a potential inducer of oxidative stress. There is also growing concern regarding the welfare of these horses; although the animals are given advanced training methods and supplementation, little is known about what really happens during and after races. The literature on the subject is scarce, and the data are controversial.

Thus, the objective of this study was to evaluate whether endurance horses racing at high speeds over different distances would develop oxidative stress, as measured by the red blood cell levels of SOD, GPx, GSH and CAT and the plasma levels of malondialdehyde (MDA).

\section{MATERIALS AND METHODS}

A total of 15 endurance horses racing in $80 \mathrm{~km}$ (two mares and three geldings, 5-8 years old), $120 \mathrm{~km}$ (two mares and three geldings, 5-8 years 
old) and $160 \mathrm{~km}$ (four geldings and one mare, 710 years old) races sanctioned by the International Federation for Equestrian Sports (FEI) in the state of São Paulo, Brazil, were included in this study.

The FMVZ-USP ethics committee approved the use of horses in this experiment and the protocol number is $2606 / 2012$.

The mean ambient temperature at the races was $28 \pm 3^{\circ} \mathrm{C}$ and the relative humidity was $76 \pm 2$. Only horses that were approved by the final veterinary evaluation participated in the study.

The animals were owned by endurance riders and housed in private stud farms and training centres, so each horse received a specific training, but used the same aerobic base, differing only in the fine adjustments. The horses received forage and commercial concentrate up to five hours before the start of the races. All animals were given supplements of electrolyte solutions during the course, had free access to water and were offered grass hay during mandatory checks.

Blood samples were collected from the jugular vein directly into vacuum tubes, and sodium heparin was used as an anticoagulant. These samples were then subjected to laboratory analyses to determine the levels of the following antioxidant enzymes: SOD, GPx, GSH and plasma MDA. EDTA was used as an anticoagulant for erythrocyte GSH.

Blood was collected prior to the start of the race (T0), immediately after leaving the last veterinary inspection (T1) and three hours after the race (T2). Samples were also collected at the stud farm three days (T3), seven days (T4) and 14 days after the race (T5).

The samples were stored on ice and transported to the laboratory, where they were centrifuged at $1,900 \mathrm{x} \mathrm{g}$ for $15 \mathrm{~min}$ at $4^{\circ} \mathrm{C}$ to separate the plasma from the red blood cells. The plasma was aliquoted into $1.5 \mathrm{~mL}$ Eppendorf tubes, which were stored in a freezer at $-80^{\circ} \mathrm{C}$ until the time of analysis. Red blood cells were resuspended in phosphate-buffered saline (PBS) and centrifuged. This washing procedure was repeated three times, and the red blood cells were stored in Eppendorf microtubes and frozen at $-80^{\circ} \mathrm{C}$. For the catalase measurements the red blood cells were stored in an EDTA solution and mercaptoethanol. The haemoglobin concentration was determined using the Drabkin's method (Beutler, 1975), where the presence of this reagent forms a compound, cyanmethaemoglobin, which absorbs at an absorbance of 540 ๆm (Celm E225, Brazil).

Erythrocyte GSH was determined by adding 1.8 $\mathrm{mL}$ of purified water to $200 \mu \mathrm{L}$ of whole blood and $3 \mathrm{~mL}$ of precipitant. After a $5 \mathrm{~min}$ rest the solution was centrifuged at $1,800 \mathrm{x} \mathrm{g}$ for $5 \mathrm{~min}$. Then $800 \mu \mathrm{L}$ of phosphate solution and $100 \mu \mathrm{L}$ of DTNB (5,5'-dithiobis-(2-nitrobenzoic acid)) were added to the $200 \mu \mathrm{L}$ of supernatant, and the samples were immediately read using a spectrophotometer at $412 \eta \mathrm{m}$ (Celm E225, Brazil) (Beutler et al., 1963).

The plasma MDA levels were determined by adding $2 \mathrm{~mL}$ of $10 \%$ trichloroacetic acid (TCA) to $1 \mathrm{~mL}$ plasma, and the samples were then centrifuged for $15 \mathrm{~min}$ at $15^{\circ} \mathrm{C}$. Then $750 \mu \mathrm{L}$ of $1 \%$ thiobarbituric acid (TBA) was added to the $750 \mu \mathrm{L}$ of supernatant, and the samples were heated in a boiling water bath for $10 \mathrm{~min}$. The tubes were cooled in ice water and the absorbance reading was collected using a spectrophotometer (Celm E225, Brazil) at 532 ๆm (Esterbauer and Cheeseman, 1990).

Catalase activity was measured according to the modified Aebi method (Aebi, 1984), by adding $20 \mu \mathrm{L}$ of haemolysate to $980 \mathrm{~mL}$ of $50 \mathrm{mmol} / \mathrm{L}$ phosphate buffer containing $10 \mathrm{mmol} / \mathrm{L}$ hydrogen peroxide. The absorbance was read using a spectrophotometer at $240 \eta \mathrm{m}$.

Following dilution, the SOD values were determined using a commercial kit (Ransod kit; Randox, United Kingdom) and a Labmax 240 automatic biochemical analyser (Labtest, Japan). The GPx levels were determined using a commercial kit (Ransel kit; Randox, United Kingdom), and the readings were performed using a Labmax 240 automatic biochemical analyser (Labtest, Japan). The haemoglobin analysis for the frozen samples was performed according to Drabkin's method to correct for the CAT, SOD and GPX results. 
The data were first tested for normality using the Kolmogorov-Smirnov test, and the results revealed that all data were parametric. The data were then analysed using a simple analysis of variance (ANOVA) and Tukey's multiple comparison test. All analyses were performed at the $5 \%$ significance level $(\mathrm{P}<0.05)$.

\section{RESULTS AND DISCUSSION}

The speed at which the horses raced ranged from 17.16 to $18.54 \mathrm{~km} / \mathrm{h}$ (160km races), 17 to $21.53 \mathrm{~km} / \mathrm{h} \quad(120 \mathrm{~km}$ races $)$ and 18.01 to $20.06 \mathrm{~km} / \mathrm{h}(80 \mathrm{~km}$ races $)$, according to the official data released by the event organising committee. The median and standard deviation for all variables evaluated at each blood collection are shown in Table 1.

Table 1. Median and standard deviation for the SOD, GPx, GSH, CAT and MDA concentrations from horses in 160-, 120- and 80km races at all blood collection times

\begin{tabular}{|c|c|c|c|c|c|}
\hline Moments & $\begin{array}{c}\text { SOD } \\
(\mathrm{U} / \mathrm{gHb})\end{array}$ & $\begin{array}{c}\text { GPx } \\
(\mathrm{U} / \mathrm{gHb})\end{array}$ & $\begin{array}{c}\text { GSH } \\
(\mu \mathrm{mol} / \mathrm{L})\end{array}$ & $\begin{array}{c}\text { CAT } \\
(\mathrm{K} / \mathrm{gHb})\end{array}$ & $\begin{array}{c}\text { MDA } \\
(\mu \mathrm{mol} / \mathrm{L})\end{array}$ \\
\hline & \multicolumn{5}{|c|}{$160 \mathrm{~km}$} \\
\hline \multirow{3}{*}{ T0 } & 2515 & 528.7 & 28.1 & 8.1 & 0.5 \\
\hline & $(651.7)$ & $(58.5)$ & (2.9) & (3.6) & $(0.1)$ \\
\hline & 2209.2 & 473.6 & 30.8 & 6.61 & 0.4 \\
\hline \multirow[t]{2}{*}{$\mathrm{T} 1$} & (269.6) & (96.7) & (4.8) & (2.1) & $(0.2)$ \\
\hline & 2180.4 & 500.6 & 29.6 & 4.05 & 0.3 \\
\hline \multirow[t]{2}{*}{$\mathrm{T} 2$} & $(340)$ & (40.9) & (5.2) & (1.2) & $(0.1)$ \\
\hline & 1972.3 & 386.2 & 25.8 & 6.82 & 0.3 \\
\hline \multirow[t]{2}{*}{$\mathrm{T} 3$} & $(756.9)$ & (181.3) & (5.7) & (6.1) & $(0.1)$ \\
\hline & 2020.4 & 361 & 24.6 & 3.96 & 0.4 \\
\hline \multirow[t]{2}{*}{$\mathrm{T} 4$} & $(813)$ & (91.4) & (8.2) & (1.5) & $(0.1)$ \\
\hline & 1809.1 & 454 & 25.6 & 3.17 & 0.4 \\
\hline \multirow[t]{2}{*}{$\mathrm{T} 5$} & (459.8) & (102.4) & $(8.2)$ & (1.8) & $(0.1)$ \\
\hline & \multicolumn{5}{|c|}{$120 \mathrm{~km}$} \\
\hline \multirow{3}{*}{ T0 } & 2154.3 & 473.8 & 31.1 & 7.2 & 0.3 \\
\hline & $(452.3)$ & (93.3) & (5.9) & (5.1) & $(0.1)$ \\
\hline & 2023.3 & 423.8 & 33.2 & 6.8 & 0.6 \\
\hline \multirow[t]{2}{*}{$\mathrm{T} 1$} & (343.4) & (143.3) & (5.7) & (2) & $(0.4)$ \\
\hline & 2284.5 & 448 & 33.9 & 4.2 & 0.3 \\
\hline \multirow[t]{2}{*}{$\mathrm{T} 2$} & $(405.1)$ & (106.3) & (6.1) & (0.8) & $(0.1)$ \\
\hline & 1855.4 & 382.8 & 19.4 & 4.3 & 0.3 \\
\hline \multirow[t]{2}{*}{$\mathrm{T} 3$} & (691.6) & $(227.4)$ & (9.8) & (1.6) & $(0.1)$ \\
\hline & 1884.1 & 341.6 & 29.3 & 5.4 & 0.3 \\
\hline \multirow[t]{2}{*}{$\mathrm{T} 4$} & (813.2) & (220) & (2.7) & (2.3) & $(0.1)$ \\
\hline & 2152 & 427.8 & 26.8 & 2.1 & 0.3 \\
\hline \multirow[t]{2}{*}{ T5 } & $(1059.5)$ & (207) & (5.7) & $(0.4)$ & $(0.1)$ \\
\hline & \multicolumn{5}{|c|}{$80 \mathrm{~km}$} \\
\hline \multirow{3}{*}{ T0 } & 1995.1 & 600 & 24.5 & 9.0 & 0.3 \\
\hline & (267) & (63.3) & (7.3) & (2.4) & (0.1) \\
\hline & 2221.6 & 605.1 & 30.2 & 7.6 & 0.5 \\
\hline \multirow[t]{2}{*}{$\mathrm{T} 1$} & $(291.2)$ & (108.9) & (9.7) & (0.9) & (0.1) \\
\hline & 2241.5 & 540.9 & 30.2 & 7.3 & 0.3 \\
\hline \multirow[t]{2}{*}{$\mathrm{T} 2$} & (391.3) & $(127.1)$ & (10.4) & (3.5) & (0.1) \\
\hline & 2290.4 & 490.6 & 24.4 & 4.1 & 0.3 \\
\hline \multirow[t]{2}{*}{$\mathrm{T} 3$} & (707.1) & (160.4) & (9.1) & (1.3) & (0.1) \\
\hline & 1974.1 & 503.3 & 24.4 & 3.4 & 0.4 \\
\hline \multirow[t]{2}{*}{$\mathrm{T} 4$} & (748.6) & $(202.3)$ & (12.1) & (0.9) & $(0.2)$ \\
\hline & 1726 & 464.2 & 24.4 & 3.3 & 0.3 \\
\hline T5 & (498.4) & (119.3) & (10.1) & (2.9) & $(0.2)$ \\
\hline
\end{tabular}

T0: prior to the start of the race; T1: immediately after leaving the last veterinary inspection; T2: three hours after the race; T3: three days after the race; T4: seven days after the race; and T5: 14 days after the race. 
The literature available on oxidative stress induced by training or competition in endurance horses is scarce and is focused on food supplementation (Williams et al., 2004; GomesCabrera et al., 2006; Williams, 2010; Smarsh et al., 2010). However, the products of lipid peroxidation, such as MDA, can be used as indicators of free radical activity, i.e., lipid peroxidation, in the body (Kirschvink et al., 2007). Although the numerical values indicated an increase immediately after the race and a return to baseline levels three hours after the race in all horses, the races were very demanding, and there were no significant differences between categories at T0 $(\mathrm{P}=0.140), \mathrm{T} 1(\mathrm{P}=0.882), \mathrm{T} 2$ $(\mathrm{P}=0.983), \mathrm{T} 3(\mathrm{P}=0.843), \mathrm{T} 4(\mathrm{P}=0.537)$ or $\mathrm{T} 5$ $(\mathrm{P}=0.476)$. The study by Williams et al. (2004) examined oxidative stress in horses performing $80 \mathrm{~km}$ races and came to the same conclusion; using different lipid peroxidation markers (LPO and TBARS), these authors observed increased oxidative stress following the cessation of exercise but a return to baseline levels within a few hours.

Although no significant differences between categories were found, fluctuations in the concentrations of antioxidant enzymes were observed. SOD is present in virtually all aerobic organisms and is part of a group of metalloenzymes that combat the toxicity of the superoxide anion (Ferreira and Matsubara, 1997). No significant differences were observed between the collection times in the $160 \mathrm{~km}(\mathrm{P}=$ $0.520), 120 \mathrm{~km}(\mathrm{P}=0.902)$ and $80 \mathrm{~km}(\mathrm{P}=0.517)$ race categories.

However, baseline SOD values were higher in horses participating in the $160 \mathrm{~km}$ race. According to Fielding and Meydani (1997), increased SOD activity corresponds to increased resistance to oxidative stress. Individuals receiving single session (acute exercise) exercise have increased their antioxidant defences. The chronic training promotes definitive increases in these defences. Additionally, Brites et al. (1999) and Ortenblad et al. (1997) found that trained human athletes had higher baseline concentrations of this enzyme than did untrained individuals, which is in accordance with the results of the present study maybe because, according to new FEI rules for the horses competing in $80 \mathrm{~km}$ races, they must be graduated first, so they necessarily trained for at least two years.

Glutathione peroxidase is responsible for the oxidation of hydrogen peroxide and is present in the cytosol and mitochondria, where superoxide dismutase is also present. This overlapping localisation is suggestive of the sequential and essential action of the antioxidant system when dealing with free oxygen radicals (Galizia and Waitzberg, 2001). In this study no significant differences were found between collection times for the $160 \mathrm{~km}(\mathrm{P}=0.126), 120 \mathrm{~km}(\mathrm{P}=0.866)$ and $80 \mathrm{~km}(\mathrm{P}=0.490)$ race categories.

Al-Quadah and Al-Majali (2008) studied horses eliminated from races due to synchronous diaphragmatic flutters and found that MDA levels were significantly higher and GPx levels were lower after disqualification, which supports the occurrence of lipid peroxidation. Oxidative stress occurs when there is consumption of antioxidant enzymes and is indicative of a substantial production of free radicals. The study by Al-Quadah and Al-Majali (2008) also reported that the GPx levels in the eliminated animals were lower than those in the control animals that finished the race without any problems. The horses examined in the present study experienced an increase in MDA levels immediately following the race, and although the levels of certain oxidative enzymes fluctuated over the course of several days, there were no marked decreases in these levels corresponding to the increased production of MDA.

Erythrocytes are rich in glutathione, and over 95\% of these cells typically carry the reduced form (GSH). There were no significant differences between collection times for the $160 \mathrm{~km}(\mathrm{P}=0.562), 120 \mathrm{~km}(\mathrm{P}=0.160)$ and $80 \mathrm{~km}(\mathrm{P}=0.807)$ race categories.

The turnover of GSH in most tissues is very quick, and the skeletal muscle is considered to be a large reservoir for GSH, since this tissue exerts a strong influence on the plasma levels and homeostasis of GSH under both physiological and pathological conditions. Intensive endurance training appears to induce an increase in muscle GSH, but this increase only affects certain muscle groups. Erythrocyte levels of GSH were shown to increase significantly in sedentary men after 20 weeks of training; moreover, GSH levels 
were higher in trained runners than in sedentary runners and were shown to correlate with the distance covered (Ji et al., 2003). In the present study there were no significant changes in erythrocyte GSH levels, although horses in $120 \mathrm{~km}$ races exhibited higher GSH concentrations at all time points examined.

Catalase is a cytoplasmic protein that catalyses the reduction of hydrogen peroxide in the body, converting it to oxygen and water. The impressive capacity of catalase to metabolise hydrogen peroxide is dependent on its accumulation (Guemouri et al., 1991). There were no significant differences between collection times for the $160 \mathrm{~km}(\mathrm{P}=0.327)$, $120 \mathrm{~km}(\mathrm{P}=0.355)$ and $80 \mathrm{~km}(\mathrm{P}=0.550)$ race categories.

Kinnunen et al. (2005) studied the effect of $80 \mathrm{~km}$ races on oxidative stress and antioxidant defences in endurance horses and found no changes in the lipid peroxidation markers or GPx activity, although these races were held at low average speeds. The levels of catalase and GPx consumption indicated that there was free radical production but not necessarily the induction of oxidative stress. The higher baseline levels of both enzymes in horses in the $80 \mathrm{~km}$ races may have been due to a more acute response, as these are trained, but less experienced horses. The transition from training to free-speed races can be a greater stimulus for the adaptation of antioxidant systems than repeated competitions (chronic training). Gondim et al. (2009) studied horses competing in a $210 \mathrm{~km}$ multiday endurance race and found that animals that finished the race had higher antioxidant levels than did those that failed to finish.

There are specific requirements for the classification of horses in free-speed races; for a horse to qualify for $160 \mathrm{~km}$ races, it needs to have trained and raced more often than horses in lower-distance categories. A single exercise session is sufficient to produce excess free radicals and the oxidation of lipids, proteins and DNA, and redox-sensitive transcription factors are subsequently activated to promote adaptive responses. However, several repeated exercise sessions (physical training) promote proportional adaptations to oxidative stimuli (Radak et al., 2008).

\section{CONCLUSIONS}

Free radicals produced during exercise are also responsible for the adaptive processes of antioxidant systems. Endurance horses competing in free-speed endurance races have typically undergone months or even years of training, which results in increased antioxidant defences and prevents the animals from experiencing the consequences of oxidative stress, even when the intensity and distance of the race are demanding. However, additional studies focused on the effects of dietary supplementation with antioxidants during the training phase are warranted, since these supplements may disturb the adaptation of antioxidant enzymes.

\section{ACKNOWLEDGEMENTS}

The authors would like to acknowledge FAPESP (Foundation for Research Support of the State of São Paulo) for their financial support.

\section{REFERENCES}

AEBI, H. Catalase. Methods in Enzymol., v.105, p.121-126, 1984.

AL-QUDAH, K.M.; AL-MAJALI, M. Higher lipid peroxidation indices in horses eliminated from endurance race because of synchronous diaphragmatic flutter. J. Equine Vet. Sci., v.28, p.573-578, 2008.

BEUTLER, E. Red cell metabolism: a manual of biochemical methods. 2. ed. London :Grune and Stratton, 1975. p.188.

BEUTLER, E.; DURON, O.; KELLY, B.M. Improved method for the determination of blood glutathione. $J$. Lab. Clin. Med., v.61, p.882-888, 1963.

BRITES, F.D.; EVELSON, P.A.; CHRISTIANSEN, M.G. et al. Soccer players under regular training show oxidative stress but an improved plasma antioxidant status. Clin. Sci., v.96, p.381-385, 1999.

DEATON, C.M.; MARLIN, D.J. Exercise-associated oxidative stress. Clin. Techn. in Equine Pract., v.2, p.278-291, 2003.

ESTERBAUER, H. AND CHEESEMAN, K.H. Determination of aldehydic lipid peroxidation products: malonaldehyde and 4-hydroxynonenal. Methods in Enzymol., v.186, p.407-421, 1990. 
FERREIRA, A.L.A.; MATSUBARA, L.S. Radicais livres: conceitos, doenças relacionadas, sistemas de defesa e estresse oxidativo [Free radicals: concepts, related diseases, defence systems and oxidative stress]. Rev. Assoc. Med. Bras., v.43, p.61-68, 1997.

FIELDING, R.A.; MEYDANI, M. Exercise, free radical generation, and aging. Aging, v.9, p.12-18, 1997.

GALIZIA, M.S.; WAITZBERG, D.L. Mecanismo de ação dos radicais livres e antioxidantes [Mechanism of action of free radicals and antioxidants]. Rev. Bras. Nutr. Clín., v.16, p.79-89, 2001.

GOMES-CABRERA, M.C.; MARTÍNEZ, A.; SANTANGELO, G. et al. Oxidative stress in marathon runners: interest of antioxidant supplementation. British J. Nutrit., v.86, p.S31-S33, 2006.

GONDIM, F.J.; ZOPPI, C.C.; SILVEIRA, L.R. et al. Possible relationship between performance and oxidative stress in endurance horses. J. Equine Vet. Sci., v.29, p.206-212, 2009.

GUEMOURI, L.; ARTUR, Y.; HERBETH, B. et al. Biological variability of superoxide dismutase, glutathione peroxidase, and catalase in blood. Clin. Chem., v.37, p.1932-1937, 1991.

JI, L.L.; POWERS, S.K.; LEEUWENBURGH, C. Exercise training-induced alterations in skeletal muscle antioxidant capacity: a brief review. Med. Sci. in Sport and Exercise, v.31, p.987-997, 2003.

KINNUNEN, S.; ATALAY, M.; HYYPPÄ, S. et al. Effects of prolonged exercise on oxidative stress and antioxidant defence in endurance horse. J. Sports Sci. Med., v.4, p.415-421, 2005.

KIRSCHVINK, N.; MOFFARTS, B.; LEKEUX, P. The oxidant/antioxidant equilibrium in horses. The Vet. J., v.117, p.178-191, 2007.
KLAUNIG, J.E.; KAMENDULIS, L.M.; HOCEVAR, B.A. Oxidative stress and oxidative damage in carcinogenesis. Toxicologic Pathology, v.38, p.96109,2010

MARLIN, D.J.; FENN, K.; SMITH, N. et al. Changes in circulatory antioxidant status in horses during prolonged exercise. The J. Nutrit., v.132, p.1622S1627S, 2002.

ORTENBLAD, N.S.; MADSEN, K.; DJURHUUS, M.S. Antioxidant status and lipid peroxidation after short-term maximal exercise in trained and untrained humans. The Am. J. Physiol., v.272, p.R1258-R1263, 1997.

RADAK, Z.; CHUNG, H.Y.; GOTO, S. Systemic adaptation to oxidative challenge induced by regular exercise. Free Rad. Biol. \& Med., v.44, p.153-159, 2008.

SCHNEIDER, C.D.; OLIVEIRA, A.R. Radicais livres de oxigênio e exercício: mecanismos de formação e adaptação ao treinamento físico [Oxygen free radicals and exercise: the mechanisms of formation and adaptation to physical training]. Rev. Bras. Med. Esporte, v.10, p.308-312, 2004.

SMARSH, D.N.; LIBURT, N.; STRELTSOVA, J. et al. Oxidative stress and antioxidant status in intensily exercising horses administered nutraceutical extracts. Equine Vet. J., v.42, p.317-322, 2010.

WILLIAMS, C.A.; KRONFELD, D.S.; HESS, T.M. et al. Antioxidant supplementation and subsequent oxidative stress of horses during an $80 \mathrm{~km}$ endurance race. J. Anim. Sci., v.82, p.588-594, 2004.

WILLIAMS, C.A. Antioxidant supplementation to exercising horse. Rev. Bras. Zootec., v.39, p.145-150, 2010. 